\title{
PENGARUH ETOS KERJA DAN DISIPLIN KERJA TERHADAP \\ EFEKTIFITAS KINERJA ORGANISASI \\ PADA STASIUN BESAR C KEDIRI
}

\author{
Saddam Nur A; Andi Artono; Siti Wahyuni \\ Fakultas Ekonomi - Universitas Kadiri \\ E-mail : andi_artono@unik-kediri.ac.id
}

\begin{abstract}
The goal in this research is: To determine the effect of partial work ethic of the effectiveness of the organization's performance on a Large Station C Kediri, to know the influence of the partial discipline of work against the effectiveness of organizational performance At PT. KAI Station Large C Kediri, to determine the simultaneous influence of the work ethic and discipline of work against the effectiveness of organizational performance At PT. KAI Station Large C Kediri, to know the variable which is the dominant influence on the effectiveness of organizational performance At PT. KAI Station Large C Kediri. The population in this study was all employees at PT. KAI Station Large C Kediri which amounted to 36 people. Data collection techniques used are field research, namely data collection techniques by conducting research directly on the object under study. The results showed that : Variable work ethic affect the effectiveness of the organization's performance on a Large Station C Kediri, Variable labor discipline influence on the effectiveness of the organization's performance on a Large Station C Kediri, Variable work ethic and work discipline together influence the effectiveness of organizational performance on a Large Station $\mathrm{C}$ Kediri, Variable labor discipline dominant influence on the effectiveness of the organization's performance on a Large Station C Kediri.
\end{abstract}

Keyword : Work Ethic, Descipline of Work, effectiveness of Peformance

\begin{abstract}
ABSTRAK
Tujuan dalam penelitian ini adalah: untuk mengetahui pengaruh secara parsial etos kerja terhadap efektifitas kinerja organisasi pada Stasiun Besar C Kediri, untuk mengetahui pengaruh secara parsial disiplin kerja terhadap efektifitas kinerja organisasi Pada PT. KAI Stasiun Besar C Kediri, Untuk mengetahui pengaruh secara simultan etos kerja dan disiplin kerja terhadap efektifitas kinerja organisasi Pada PT. KAI Stasiun Besar C Kediri, untuk mengetahui variabel manakah yang berpengaruh dominan terhadap efektifitas kinerja organisasi Pada PT. KAI Stasiun Besar C Kediri. Populasi dalam penelitian ini adalah seluruh pegawai pada PT. KAI Stasiun Besar C Kediri yang berjumlah 36 orang. Teknik pengumpulan data yang digunakan adalah field research yaitu teknik pengumpulan data dengan cara mengadakan penelitian secara langsung terhadap obyek yang diteliti. Hasil penelitian menunjukan bahwa : Variabel etos kerja berpengaruh terhadap efektivitas kinerja organisasi pada Stasiun Besar C Kediri, variabel disiplin kerja berpengaruh terhadap efektivitas kinerja organisasi pada Stasiun Besar C Kediri, variabel etos kerja dan disiplin kerja secara
\end{abstract}


bersama-sama berpengaruh terhadap efektivitas kinerja organisasi pada Stasiun Besar C Kediri, variabel disiplin kerja berpengaruh dominan terhadap efektivitas kinerja organisasi pada Stasiun Besar C Kediri.

Kata Kunci: Etos Kerja, Disiplin Kerja, Efektifitas Kinerja.

\section{PENDAHULUAN}

Sumber daya manusia mempunyai peranan yang besar dalam suatu organisasi, terutama untuk mencapai tujuan organisasi. Keberhasilan mencapai tujuan organisasi didukung sepenuhnya oleh perilaku pegawai. Oleh karena itu, pegawai mempunyai peranan penting dalam membentuk/mengelola organisasi dan memanfaatkan teknologi. Pegawai mempunyai berbagai tanggapan yang bervariasi dari tekanan lingkungan organisasi. Kegiatan organisasi tidak akan berjalan tanpa adanya keterlibatan unsur manusia yang ada didalamnya. Sejalan dengan pentingnya sumber daya manusia dalam organisasi, bahwa manusia merupakan unsur yang paling penting menentukan keberhasilan atau kegagalan suatu organisasi dalam menyelenggarakan berbagai kegiatannya dan dalam rangka pencapaian tujuan dan sasaran instansi/organisasi (Siagian, 2001,25).

Etos kerja merupakan masalah yang tepat dan menarik untuk diperbincangkan seiring dengan meningkatnya peran sumber daya manusia dalam menghadapi perkembangan dunia yang semakin global (Rahayu \& Ruhamak, 2017). Etos kerja selalu bisa dijadikan isu penting, ditengah upaya untuk terus meningkatkan kinerja dan efisiensi nasional dalam rangka menghadapi era pasar bebas.

Kinerja suatu instansi tidak dapat berhasil atau tidak dapat tercapai dengan baik, hal ini disebabkan karena setiap pegawai atau para pelaku dalam suatu organisasi atau instansi belum menyumbangkan tenaga dan kemampuannya sesuai dengan kebutuhan instansi dan pimpinan belum mengetahui bagaimana cara mengukur tingkat sumbangan tenaga kerja dalam bentuk kinerja pegawai serta belum mengetahui kapan kinerja pegawai harus dinilai sehingga pegawai tidak bekerja secara optimum.

Kinerja pegawai akan baik bila dia mempunyai keahlian (skill) yang tinggi (Yunanto, 2017), bersedia bekerja karena di gaji atau di beri upah sesuai dengan perjanjian dan mempunyai harapan untuk masa depan yang lebih baik. Kinerja pegawai merupakan hasil dari persepsi mereka tentang pekerjaan mereka. Selain itu kinerja pegawai merupakan hasil dari persepsi mereka tentang pekerjaan mereka. Berdasarkan beberapa faktor di lingkungan kerja, seperti kondisi kerja yang dialami pegawai, kebijakan dan prosedur, gaya kepemimpinan, hubungan kelompok kerja, dan tunjangan tambahan. 


\section{Rumusan Masalah}

Adapun rumusan masalah dalam penelitian ini sebagai berikut:

1. Apakah ada pengaruh secara parsial etos kerja terhadap efektifitas kinerja organisasipadaStasiun Besar CKediri?

2. Apakah ada pengaruh secara parsialdisiplin kerja terhadap efektifitas kinerja organisasipada Stasiun Besar C Kediri ?

3. Apakah ada pengaruh secara simultan etos kerja dan disiplin kerja terhadap efektifitas kinerja organisasipada Stasiun Besar C Kediri ?

4. Variabel manakah yang berpengaruh dominan terhadap efektifitas kinerja organisasipadaStasiun Besar C Kediri ?

\section{Tujuan Penelitian}

Tujuan dalam penelitian ini adalah:

1. Untuk mengetahui pengaruh secara parsial etos kerja terhadap efektifitas kinerja organisasipada Stasiun Besar C Kediri.

2. Untuk mengetahui pengaruh secara parsialdisiplin kerja terhadap efektifitas kinerja organisasi Pada PT. KAI Stasiun Besar C Kediri.

3. Untuk mengetahui pengaruh secara simultan etos kerja dan disiplin kerja terhadap efektifitas kinerja organisasi Pada PT. KAI Stasiun Besar C Kediri.

4. Untuk mengetahui variabel manakah yang berpengaruh dominan terhadap efektifitas kinerja organisasi Pada PT. KAI Stasiun Besar C Kediri.

\section{TINJAUAN PUSTAKA}

\section{Penelitian Terdahulu}

Berikut adalah beberapa penelitian yang telah dilakukan dan dujadikan landasan pada penelitian ini :

1. Muhammad Zulham (2008) judul penelitian:Analisis Pengaruh Budaya Organisasi dan Etos Kerja Terhadap Kinerja Pegawai Fakultas Ekonomi Universitas Sumatera Utara Medan. Tesis.Sekolah PascasarjanaUniversitas Sumatera Utara Medan. Tujuan penelitian adalah untuk mengetahui dan menganalisis pengaruh budaya organisasi dan etos kerja terhadap kinerja pegawai Fakultas Ekonomi Universitas Sumatera Utara Medan. Pendekatan yang digunakan adalah survei. Jenis penelitian adalah deskriptif kuantitatif, dan sifat penelitian adalah penelitian penjelasan (explanatory). Metode pengumpulan data dilakukan dengan wawancara 
(interview), daftar pertanyaan (questionaire), dan studi dokumentasi. Model analisis data yang digunakan adalah analisis regresi linier berganda. Populasi penelitian ini adalah seluruh pegawai Fakultas Ekonomi Universitas Sumatera Utara Medan yang berjumlah 65 orang. Teknik penentuan sampel dalam penelitian ini adalah sampel jenuh (sensus). Dengan demikian jumlah sampel sama dengan jumlah populasi, yaitu sejumlah 65 orang pegawai Fakultas Ekonomi USU. Kesimpulan penelitian adalah budaya organisasidan etos kerja secara simultan maupun parsial berpengaruh signifikan terhadap kinerja pegawai Fakultas Ekonomi USU Medan.

2. Kusnan (2004) meneliti dengan judul "Analisis Sikap Iklim Organisasi, Etos Kerja dan Disiplin Kerja Dalam Menentukan Efektivitas Kinerja Organisasi Di Garnisun Tetap III Surabaya. Tujuan penelitian ini adalah untuk menganalisis iklim organisasi, etos kerja dan disiplin kerja dalam menentukan efektivitas kinerja organisasi. Populasi dalam penelitian ini adalah kepada seluruh prajurit dan pegawai sipil organisasi Garnisun Tetap III yang berjumlah 212 orang. Penentuan sampel dalam penelitian ini menggunakan stratified random sampling, dan jumlah sampel 62 orang terdiri dari tingkatan/ strata TNI, AD, AL, AU maupun pegawai sipil dari Garnisun Tetap III Surabaya. Metode analisis data menggunakan regresi linier berganda. Hasil penelitian menunjukkan bahwa iklim organisasi dan etos kerja di Garnisun Tetap III Surabaya tidak berpengaruh signifikan terhadap efektivitas kinerja organisasi. Sedangkan disiplin kerja di Garnisun Tetap III Surabaya berpengaruh signifikan terhadap efektivitas kinerja organisasi.

\section{Landasan Teori}

\section{Manajemen Sumber Daya Manusia}

Manajemen Sumber Daya Manusia-SDM (human resourses-HR management) adalah sebuah proses dalam menangani karyawan, buruh dan lainnya supaya kita dapat memperoleh hasil yang maksimal dalam pekerjaan yang dilakukan karyawan tersebut pada perusahaan atau sebuah organisasi yang dinaungi.

\section{Efektivitas Kinerja Organisasi}

Adapun efektivitas kinerja organisasi menurut E.M. Agus D, dkk $(2001,36)$, yaitu: "Dalam melakukan pekerjaan, pada hakekatnya para pekerja memerlukan rasa aman, yang mempunyai kaitan dengan (1). Jaminan masa depan, (2). Suasana organisasi yang 
memberikan kesempatan untuk berkembang, tanpa adanya acaman-acaman, (3). Hubungan antara atasan dan bawahan yang manusiawi”.

Oleh karena itu, dapat disimpulkan bahwa efektivitas kinerja organisasi merupakan susunan dari beberapa orang secara rapi yang menggambarkan seluruh siklus input-proses-output untuk mencapai tujuan yang diharapkan.

\section{Etos Kerja}

Setiap organisasi yang selalu ingin maju, akan melibatkan anggota untuk meningkatkan mutu kinerjanya, diantaranya setiap organisasi harus memiliki etos kerja. Etos kerja adalah sebagai kesuksesan yang dapat dicapai individu di dalam melaksanakan pekerjaan yang ukuran kesuksesannya tidak dapat

Menurut Nurcholls dalam Tasmara, $(2000,110)$ "etos berasal dari bahasa Yunani (ethos), artinya watak atau karakter". Secara lengkap ethos ialah watak atau karakter dan sikap, budaya kerja serta kepercayaan dan seterusnya yang bersifat khusus tentang seseorang individu atau sekelompok manusia. Sedangkan menurut Pandji Anoraga dan Sri Suryanti (1995), "etos kerja diartikan sebagai pandangan dan sikap suatu bangsa atau umat terhadap kerja."

\section{Disiplin Kerja}

Menurut Nitisemito (2006:199) menyatakan bahwa“masalah kedisiplinan kerja, merupakan masalah yang perlu diperhatikan, sebab dengan adanya kedisiplinan, dapat mempengaruhi efektivitas dan efisiensi pencapaian tujuan organisasi." Sedangkan menurut Greenberg dan Baron $(2003,104)$ "memandang disiplin melalui adanya hukuman." Menurut Subekti (2005) "Disiplin kerja, pada dasarnya dapat diartikan sebagai bentuk ketaatan dari perilaku seseorang dalam mematuhi ketentuan-ketentuan ataupun peraturan-peraturan tertentu yang berkaitan dengan pekerjaan, dan diberlakukan dalam suatu organisasi atau perusahaan."

Berdasarkan pengertian diatas disimpulkan bahwa disiplin kerja merupakan suatu sikap, tingkah laku, dan perbuatan yang sesuai dengan peraturan baik tertulis maupun tidak tertulis, dan bila melanggar akan ada sanksi atas pelanggarannya.

\section{Kerangka Berfikir}

Kerangka pemikiran dalam penelitian ini dapat digambarkan sebagai berikut 


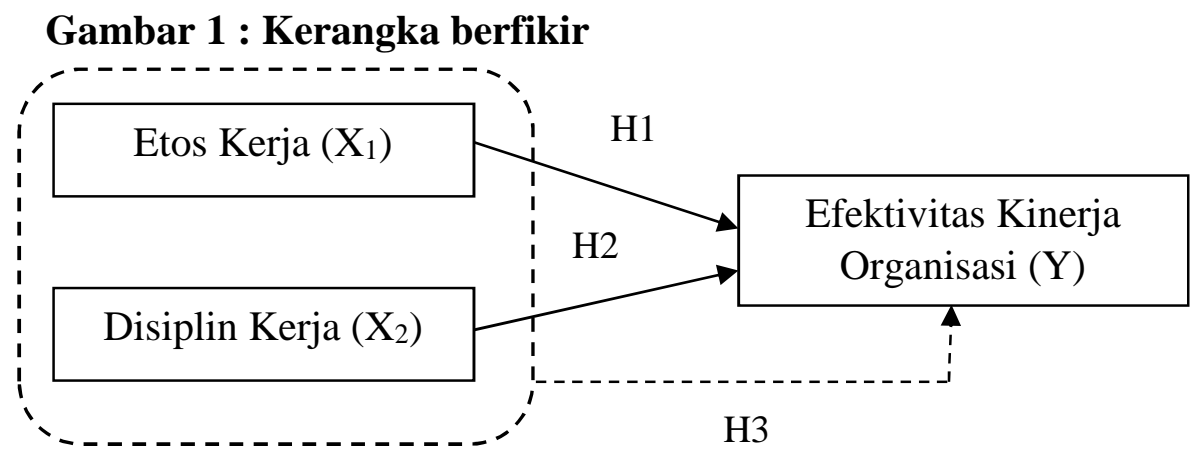

\section{Hipotesis}

H1 : Variabel etos kerja berpengaruh terhadap efektifitas kinerja organisasi pada PT.KAI Stasiun Besar C Kediri.

H2 : Variabel disiplin kerja berpengaruh terhadapefektifitas kinerja organisasi pada PT.KAI Stasiun Besar C Kediri.

H3 : Variabel etos kerja dan disiplin kerja secara simultan berpengaruh terhadap efektifitas kinerja organisasi pada PT. KAI Stasiun Besar C Kediri.

\section{METODE PENELITIAN}

\section{Populasi dan Sampel Penelitian}

Metode pengambilan sampel atau pengambilan populasi penelitian sangat penting. Menurut (Sugiyono, 2005,57) populasi adalah wilayah generalisasi yang terdiri atas obyek/subyek yang mempunyai kuantitas dan karakteristik tertentu yang ditetapkan oleh peneliti untuk dipelajari dan kemudian ditarik kesimpulannya.

Berdasarkan pendapat di atas, maka populasi dalam penelitian ini adalah seluruh pegawai pada PT. KAI Stasiun Besar C Kediri yang berjumlah 36 orang. Menurut Arikunto (2001:134) bahwa: "apabila subyeknya lebih dari 100 (seratus) orang maka sebaiknya diambil antara $10 \%-15 \%$ atau $20 \%-25 \%$ atau lebih, sedangkan jika subyeknya kurang dari 100 orang, maka sebaiknya diambil seluruhnya.Mengingat jumlah populasi kecil yaitu di bawah 100 orang, maka tidak perlu diambil sampel penelitian sehingga penelitian ini merupakan penelitian populasi. Dengan demikian sampel dalam penelitian ini sejumlah 36 orang pegawai pada Stasiun Besar C Kediri.

\section{Metode Pengumpulan Data}

Teknik pengumpulan data yang digunakan adalah field research yaitu teknik pengumpulan data dengan cara mengadakan penelitian secara langsung 
terhadap obyek yang diteliti. Dalam penelitian ini teknik yang digunakan dalam pengumpulan data ini adalah:

1. Kuesioner

Kuesioner adalah pengambilan data dengan cara membuat daftar pertanyaanpertanyaan yang kemudian disebarkan kepada responden (obyek penelitian) sehingga memperoleh hasil atau jawaban yang dikehendaki. Adapun kuesioner terlampir.

2. Dokumentasi

Dokumentasi yaitu pengumpulan data yang diperoleh dari catatan atau dokumen-dokumen yang dibutuhkan dan berkaitan dengan permasalahan penelitian ini.

Data yang digunakan dalam penelitian ini merupakan data primer dan data sekunder. Data primer yaitu data yang diperoleh dengan melakukan penelitian secara langsung dari suatu tempat yang menjadi obyek penelitian. Dalam hal ini pegawai Stasiun Besar Kediri dengan cara memberikan kuesioner mengenai etose kerja, disiplin kerja dan efektivitas kinerja organisasi. Sedangkan data sekunder hanya sebagai penunjang yang dibutuhkan dalam penelitian inimeliputi gambaran umum perusahaan dan struktur organisasi.

\section{Uji Validitas}

Uji validitas digunakan untuk mengukur sah/valid tidaknya suatu kuisioner.

\section{Uji Reliabilitas}

Reliabilitas adalah alat untuk mengukur kuesioner yang merupakan indikator dari variabel (Imam Ghozali, 2001:132). Teknik perhitungan koefisien reliabilitas yang digunakan disini adalah dengan menggunakan Alpha Cronbach. Bila $\alpha \geq 0,6$ data layak dipergunakan untuk penelitian. Uji validitas dan reliabilitas dianalisa secara komputasi dengan menggunakan program SPSS.

\section{METODE ANALISIS DATA}

\section{Uji Asumsi Klasik Multikolinearitas}

Multikolineritas adalah keadaan di mana terjadi hubungan linier yang sempurna atau mendekati sempurna antar variable independent dalam model regresi. Uji multikolinearitas digunakan untuk mengetahui ada atau tidaknya hubungan linier antar variable independent dalam model regresi. Prasyarat yang harus terpenuhi dalam model regresi adalah ada tidaknya multikolinearitas. 


\section{Uji Normalitas}

Priyatno (2010) menyatakan bahwa uji normalitas digunakan untuk mengetahui apakah populasi data berdistribusi normal atau tidak. Uji ini biasanya digunakan untuk mengukur data berskala ordinal, interval, ataupun rasio.

\section{Regresi Linier Berganda}

Regresi linier berganda digunakani untuk mengetahui sejauhmana variabel bebas berpengaruh terhadap variabel terikat, dengan rumus persamaan sebagai berikut :

$$
\mathrm{Y}=\mathrm{a}+\mathrm{b}_{1} \mathrm{X}_{1}+\mathrm{b}_{2} \mathrm{X}_{2}+\mathrm{e}
$$

\section{Uji F}

Digunakan untuk menguji apakah ada hubungan signifikan antara variabel bebas dengan variabel terikat secara bersama-sama (Sudjana, 2005:108).

\section{Koefisien Determinasi $\left(\mathbf{R}^{2}\right)$}

Analisa determinasi digunakan untuk mengetahui hubungan secara simultan variabel bebas dengan variabel terikat (Sugiono, 2005:78).

\section{HASIL \& PEMBAHASAN}

\section{Uji Validitas}

\section{Tabel 1 Rangkuman Hasil Uji Validitas Variabel Etos Kerja $\left(\mathbf{X}_{1}\right)$}

\begin{tabular}{|c|c|c|c|c|}
\hline NO. & Item & r hitung & r tabel & Keterangan \\
\hline 1. & 1 & 0,403 & 0,3 & Valid \\
\hline 2. & 2 & 0,730 & 0,3 & Valid \\
\hline 3. & 3 & 0,639 & 0,3 & Valid \\
\hline 4. & 4 & 0,756 & 0,3 & Valid \\
\hline 5. & 5 & 0,479 & 0,3 & Valid \\
\hline
\end{tabular}

Sumber : Data diolah 2017

Tabel 2 Rangkuman Hasil Uji Validitas Variabel Disiplin Kerja $\left(\mathbf{X}_{2}\right)$

\begin{tabular}{|c|c|c|c|c|}
\hline NO. & Item & r hitung & r tabel & Keterangan \\
\hline 1. & 1 & 0,661 & 0,3 & Valid \\
\hline 2. & 2 & 0,763 & 0,3 & Valid \\
\hline 3. & 3 & 0,842 & 0,3 & Valid \\
\hline 4. & 4 & 0,722 & 0,3 & Valid \\
\hline
\end{tabular}

Sumber : Data diolah 2017 
Tabel 3 Hasil Uji Validitas Variabel Efektivitas Kinerja Organisasi (Y)

\begin{tabular}{|c|c|c|c|c|}
\hline NO. & Item & r hitung & r tabel & Keterangan \\
\hline 1. & 1 & 0,525 & 0,3 & Valid \\
\hline 2. & 2 & 0,857 & 0,3 & Valid \\
\hline
\end{tabular}

Sumber : Data diolah 2017

Berdasarkan tabel uji validitas diatas adalah seluruh item pertanyaan yang ada pada setiap variable dinyatakan valid karena angka signifikasinya lebih kecil dari 0,05 dan nilai $r$ tabel lebih kecil dari rhitung.

\section{Uji Reliabilitas}

Tabel 4 Rangkuman Hasil Uji Reliabilitas Variabel $X_{1}, X_{2}$ Dan $Y$

\begin{tabular}{|c|c|c|c|c|}
\hline NO. & Variabel & Alpha hitung & Alpha Cronbach kritis & Keterangan \\
\hline 1. & $\mathrm{X}_{1}$ & 0,735 & 0,6 & Reliabel \\
\hline 2. & $\mathrm{X}_{2}$ & 0,798 & 0,6 & Reliabel \\
\hline 3. & $\mathrm{Y}$ & 0,754 & 0,6 & Reliabel \\
\hline
\end{tabular}

Sumber : Data diolah 2017

Berdasarkan tabel di atas dapat diketahui bahwa pengujian reliabilitas terhadap variabel etos kerja $\left(\mathrm{X}_{1}\right)$ menunjukan bahwa item-item pertanyaan variabel etos kerja adalah reliabel dan layak untuk digunakan dalam penelitian sebab nilai $\alpha$ sebesar 0,735 $>0,6$.

Pengujian reliabilitas variabel disiplin kerja $\left(\mathrm{X}_{2}\right)$ menunjukan bahwa item-item pertanyaan variabel disiplin kerja adalah reliabel dan layak untuk digunakan dalam penelitian sebab nilai $\alpha$ sebesar 0,798 > 0,6.

Pengujian reliabilitas terhadap variabel efektivitas kinerja organisasi (Y) menunjukan bahwa item-item pertanyaan variabel efektivitas kinerja organisasi adalah reliabel dan layak untuk digunakan dalam penelitian sebab nilai $\alpha$ sebesar 0,754 > 0,6.

\section{Uji Asumsi Klasik Multikolinearitas}

\section{Tabel 5 Uji Multikolinieritas}

\section{COEFFICIENTS}

\begin{tabular}{|c|c|c|c|c|c|c|c|}
\hline \multirow[b]{2}{*}{ Model } & \multicolumn{2}{|c|}{$\begin{array}{l}\text { Unstandardized } \\
\text { Coefficients }\end{array}$} & \multirow{2}{*}{$\begin{array}{c}\begin{array}{c}\text { Standardized } \\
\text { Coefficients }\end{array} \\
\text { Beta }\end{array}$} & \multirow[b]{2}{*}{$\mathrm{t}$} & \multirow[b]{2}{*}{ Sig. } & \multicolumn{2}{|c|}{ Collinearity Statistics } \\
\hline & $\mathrm{B}$ & Std. Error & & & & Tolerance & VIF \\
\hline $1 \quad$ (Constant) & -.322 & .363 & & -.887 & .381 & & \\
\hline etos kerja & .289 & .121 & .215 & 2.387 & .023 & .532 & 1.879 \\
\hline disiplin kerja & .790 & .093 & .765 & 8.481 & .000 & .532 & 1.879 \\
\hline
\end{tabular}

a. Dependent Variable: kinerja organisasi

Sumber : Output SPSS 
Dari tabel diatas dapat diketahui bahwa nilai VIF untuk etos kerja sebesar 1,879 dan disiplin kerja sebesar 1,879. Karena nilai VIF kurang dari 5, maka dapat disimpulkan bahwa pada model regresi tidak ditemukan adanya masalah multikolinearitas.

\section{Uji Normalitas}

Uji normalitas dapat dilakukan dengan P-Plot ( Probability Plot ) yang dasar pengambilan keputusannya sebagai berikut:

1) Jika data menyebar dan mengikuti garis diagonal maka data terdistribusi normal dan memenuhi asumsi klasik.

2) Jika data jauh di atas garis diagonal dan tidak mengikuti arah garis diagonal maka model regresi tidak memenuhi asumsi klasik.

Hasil uji normalitas dengan menggunakan P-Plot dapat dilihat sebagai berikut:

\section{Gambar 2 Grafik Normalitas Probability Plot}

Normal P-P Plot of Regression Standardized Residual

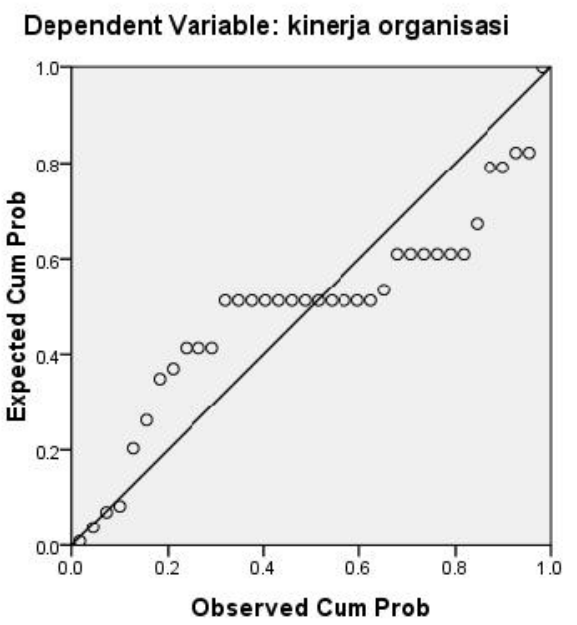

Sumber : Output SPSS

Berdasarkan gambar 2 grafik normal probability plot di atas diketahui bahwa titik-titik menyebar dan mengikuti garis diagonal, dengan demikian dapat disimpulkan bahwa data terdistribusi secara normal. Jadi kedua grafik tersebut menunjukkan bahwa model regresi layak dipakai karena memenuhi asumsi normalitas. 


\section{Model Regresi Linier Berganda}

\begin{tabular}{|c|c|c|c|c|c|c|}
\hline \multicolumn{7}{|c|}{ Coefficientsa } \\
\hline \multirow{2}{*}{\multicolumn{2}{|c|}{ Model }} & \multicolumn{2}{|c|}{ Unstandardized Coefficients } & \multirow{2}{*}{$\begin{array}{c}\begin{array}{c}\text { Standardized } \\
\text { Coefficients }\end{array} \\
\text { Beta }\end{array}$} & \multirow[b]{2}{*}{$\mathrm{t}$} & \multirow[b]{2}{*}{ Sig. } \\
\hline & & B & Std. Error & & & \\
\hline 1 & (Constant) & -.322 & .363 & & -.887 & .381 \\
\hline & etos kerja & .289 & .121 & .215 & 2.387 & .023 \\
\hline & disiplin kerja & .790 & .093 & .765 & 8.481 & .000 \\
\hline
\end{tabular}

a. Dependent Variable: kinerja organisasi

Sumber : Output SPSS

\section{Tabel 6 Model Regresi Linier Berganda}

Berdasarkan tabel 5, maka model persamaan regresi linier yang dihasilkan dalam penelitian ini adalah:

$Y=-0,322+0,289 X_{1}+0,790 X_{2}$

Nilai konstanta sebesar -0,322 menunjukkan bahwa apabila variabel etos kerja dan disiplin kerja diabaikan dalam analisis, maka efektivitas kinerja organisasi Stasiun Besar Kediri (Y) sebesar 0,322.

Interpretasi dari model persamaan regresi tersebut, sebagai berikut:

1. Pengaruh antara etos kerja $\left(\mathrm{X}_{1}\right)$ terhadap efektivitas kinerja organisasi Stasiun Besar Kediri (Y)

a. Koefisien regresi variabel etos kerja $\left(\mathrm{X}_{1}\right)$ diketahui sebesar 0,289. Hal ini menunjukkan bahwa hubungan antara variabel Etos kerja terhadap efektivitas kinerja organisasi Stasiun Besar Kediri (Y) adalah positif atau searah artinya apabila variabel etos kerja naik maka efektivitas kinerja organisasi Stasiun Besar Kediri akan naik dengan catatan variabel X2 tetap.

b. Nilai t hitung untuk variabel etos kerja (X1) sebesar 2,387 dan nilai sig. sebesar 0,023 atau 2,3\% maka berarti pengaruh Etos kerja terhadap efektivitas kinerja organisasi Stasiun Besar Kediri (Y) sangat bermakna atau signifikan pada taraf signifikan 95\%. Sebab t hitungnya $=2,387$ lebih besar dari pada $\mathrm{t}$ tabelnya $=1,987$ atau sig. sebesar 0\% lebih kecil dari 5\%. Dengan kata lain Ho ditolak dan $\mathrm{Ha}$ diterima, artinya ada pengaruh Etos kerja terhadap efektivitas kinerja organisasi Stasiun Besar Kediri.

2. Pengaruh antara disiplin kerja (X2) terhadap efektivitas kinerja organisasi Stasiun Besar Kediri (Y) 
a. Koefisien regresi variabel disiplin kerja (X2) diketahui sebesar 0,790. Hal ini menunjukkan bahwa hubungan antara variabel disiplin kerja terhadap efektivitas kinerja organisasi Stasiun Besar Kediri (Y) adalah positif atau searah artinya apabila variabel disiplin kerja naik maka efektivitas kinerja organisasi Stasiun Besar Kediri akan naik sebesar 0,790 dengan catatan variabel $\mathrm{X}_{1}$ tetap.

b. Nilai t hitung untuk variabel disiplin kerja $\left(\mathrm{X}_{2}\right)$ sebesar 8,481 dan nilai sig. sebesar 0,000 atau $0 \%$ maka berarti pengaruh disiplin kerja terhadap efektivitas kinerja organisasi Stasiun Besar Kediri (Y) sangat bermakna atau signifikan pada taraf signifikan 95\%. Sebab t hitungnya $=8,481$ lebih besar dari pada t tabelnya $=1,987$ atau sig. sebesar 1,9\% lebih kecil dari 5\%. Dengan kata lain Ho ditolak dan Ha diterima, artinya ada pengaruh antara disiplin kerja terhadap efektivitas kinerja organisasi Stasiun Besar Kediri.

Uji f

Tabel 7 ANOVA

\begin{tabular}{|ll|r|r|r|r|r|}
\hline Model & & Sum of Squares & df & Mean Square & F & Sig. \\
\hline 1 & Regression & 7.065 & 2 & 3.532 & 98.913 & $.000^{\circ}$ \\
& Residual & 1.178 & 33 & .036 & & \\
& Total & 8.243 & 35 & & & \\
\hline
\end{tabular}

a. Predictors: (Constant), disiplin kerja, etos kerja

b. Dependent Variable: kinerja organisasi

Berdasarkan tabel di atas dapat diketahui bahwa nilai $\mathrm{F}$ hitung sebesar 98,913. Sedangkan nilai dari F tabel pada derajat keyakinan 95\% adalah 3,284. Dengan demikian dapat diketahui bahwa secara simultan variabel etos kerja $\left(\mathrm{X}_{1}\right)$ dan disiplin kerja $\left(\mathrm{X}_{2}\right)$ berpengaruh terhadap efektivitas kinerja organisasi pada Stasiun Besar Kediri secara nyata atau signifikan, karena $\mathrm{F}$ hitung lebih besar dan $\mathrm{F}$ tabel, pada tingkat keyakinan $95 \%$.

Hal ini juga dapat dilihat dan tingkat signifikansi $(\alpha)$ yang ditetapkan dalam penelitan ini adalah 5\% (0,05), sedangkan pengaruh kedua variabel bebas (X) secara simultan terhadap variabel efektivitas kinerja organisasi pada Stasiun Besar Kediri dalam tabel 4.13 adalah $0,000<\alpha(0,05)$, maka Ho ditolak. Dengan demikian Ha diterima, artinya kedua variabel bebas, yaitu Etos kerja $\left(\mathrm{X}_{1}\right)$ dan disiplin kerja $\left(\mathrm{X}_{2}\right)$ secara simultan memiliki pengaruh yang signifikan terhadap efektivitas kinerja organisasi pada Stasiun Besar Kediri.

\section{Analisa Koefisien Determinasi $\left(\mathbf{R}^{2}\right)$}

Sedangkan hasil analisis determinasi (R2) dapat dilihat pada di bawah ini. 
Tabel 8 Analisa Koefisien Determinasi $\left(\mathbf{R}^{2}\right)$

\begin{tabular}{|c|c|c|c|c|}
\hline Model & $\mathrm{R}$ & $\mathrm{R}$ Square & $\begin{array}{c}\text { Adjusted } \mathrm{R} \\
\text { Square }\end{array}$ & $\begin{array}{c}\text { Std. Error of the } \\
\text { Estimate }\end{array}$ \\
\hline 1 & $.926^{\mathrm{a}}$ & .857 & .848 & .18897 \\
\hline
\end{tabular}

a. Predictors: (Constant), disiplin kerja, etos kerja

Sumber: Output SPSS

Berdasarkan tabel di atas, dapat dijelaskan bahwa nilai koefisien determinasi $\left(\mathrm{R}^{2}\right)$ yang diperoleh adalah 0,857 . Artinya bahwa kedua variabel bebas, yaitu etos kerja (X1) dan disiplin kerja (X2) memberikan kontribusi pada efektivitas kinerja organisasi pada Stasiun Besar Kediri sebesar 85,7\% sedangkan 14,3\% lainnya dapat dijelaskan oleh variabel lain yang tidak termasuk dalam penelitian.

\section{KESIMPULAN DAN SARAN}

\section{Kesimpulan}

Berdasarkan analisis data dan pembahasan hasil penelitian, maka dapat disimpulkan temuan penelitian sebagai berikut:

1. Variabel etos kerja berpengaruh terhadap efektivitas kinerja organisasi pada Stasiun Besar C Kediri.

2. Variabel disiplin kerja berpengaruh terhadap efektivitas kinerja organisasi pada Stasiun Besar C Kediri.

3. Variabel etos kerja dan disiplin kerja secara bersama sama berpengaruh terhadap efektivitas kinerja organisasi pada Stasiun Besar C Kediri.

4. Variabel disiplin kerja berpengaruh dominan terhadap efektivitas kinerja organisasi pada Stasiun Besar C Kediri.

\section{Saran}

Dalam menunjang tercapainya tujuan perusahaan maka beberapa saran yang dapat dikemukakan demi suksesnya aktivitas usaha adalah :

1. Hendaknya manajemen perusahaan berusaha meningkatkan etos kerja pegawai.

2. Hendaknya manajemen perusahaan berupaya meningkatkan disiplin kerja pegawai.

\section{DAFTAR PUSTAKA}

Alex S. Nitisemito, 2002, Manajemen Personalia, Edisi Ketiga, Jakarta: Penerbit Ghalia Indonesia.

Rahayu, B., \& Ruhamak, M. D. (2017). Pengaruh Kepemimpinan, Insentif, Remunerasi Dan Motivasi Terhadap Kinerja Karyawan (Studi Kasus Pada PT Industri Sandang 
Pangan Nusantara Cilacap). EKONIKA, 2(1), 1-22.

https://doi.org/http://dx.doi.org/10.30737/ekonika.v2i1.15

Yunanto, Y. (2017). PENGARUH KUALITIAS PEAYANAN DAN DISIPLIN KERJA ARYAWAN BIRO ADMINISTRASI UMUM TERHADAP KEPUASAN

MAHASISWA, 15(2), 99-104.

Duwi Priyatno, 2010, Paham Analisa Statistik Data dengan SPSS, Jakarta: Mediakom.

Flippo B. Edwin, 2004, Manajemen Personalia, Edisi Keenam, Jilid I, alih bahasa oleh Moh.Masud, Jakarta: Penerbit Erlangga.

Fathoni, Abdurrahman (1996). Organisasi dan Manajemen, Garut, Fakultas Ekonomi Universitas Garut (UNIGA).

Imam Ghozali, 2001. Aplikasi Analisis Multivariate dengan program SPSS. Badan. Semarang:Penerbit Universitas Diponegoro.

Kusnan (2004) meneliti dengan judul "Analisis Sikap Iklim Organisasi, Etos Kerja dan Disiplin Kerja Dalam Menentukan Efektivitas Kinerja Organisasi Di Garnisun Tetap III Surabaya.

Nasir M., (1995). Metodologi penelitian. Penerbit Eresco, Jakarta.

Muhammad Zulham (2008) judul penelitian Analisis Pengaruh Budaya Organisasi dan Etos Kerja Terhadap Kinerja Pegawai Fakultas Ekonomi Universitas Sumatera Utara Medan. Tesis. Sekolah Pascasarjana Universitas Sumatera Utara Medan.

Soekanto. 2006. Sosiologi Suatu Pengantar. Jakarta: Raja Grafindo Persada.

Sinarimbum Masri, Effendi Sofian, (2005), Metode penelitian survey, LP3 Ekonomi dan Sosial, Jakarta.

Sondang Siagian. 2001. Manajemen Stratejik. Edisi keenam. Jakarta: PT. Bumi Aksara.

Strees, R. M., 1985, Efektivitas organisasi, Erlangga, Jakarta.

Sugiyono. 2005 Statistik Non Parametik. Bandung : Al Fabeta.

Suharsimi Arikunto. 2005. Metodologi Penelitian. Penerbit PT. Rineka Cipta.

Sudjana, 2005, Metode Statistika, Bandung: Penerbit Tarsito. 